\title{
Nitrogen use efficiency of bread wheat: Effects of nitrogen rate and time of application
}

\author{
D. Haile ${ }^{1 *}$, D. Nigussie ${ }^{1}$ and A. Ayana ${ }^{2}$ \\ ${ }^{1}$ Haramaya University, P.O. Box, 138, Dire Dawa, Ethiopia. ${ }^{2}$ Oromia Agricultural Research Institute, P.O. Box: \\ 81265, Addis Ababa, Ethiopia. "Corresponding author: haile2km@gmail.com
}

\begin{abstract}
The experiment was conducted to assess the effects of nitrogen $(\mathrm{N})$ rate and time of application on $\mathrm{N}$ use efficiency (NUE) of bread wheat, and their association with grain yield and protein content. Factorial combinations of four $\mathrm{N}$ levels, two bread wheat varieties and three timings of $\mathrm{N}$ applications were laid out in a randomized complete block design. $\mathrm{N}$ rate significantly influenced grain yield, protein content, $\mathrm{N}$ uptake efficiency, $\mathrm{N}$ biomass production efficiency, $\mathrm{N}$ utilization efficiency, $\mathrm{N}$ use efficiency for grain and $\mathrm{N}$ use efficiency for protein yield. Time of $\mathrm{N}$ application had highly significant effect on grain yield, protein content and NUE traits. Rate of N application and variety were significantly interacted to influence grain yield. Grain yield for Madda Walabu found sharply increase with each increase in $\mathrm{N}$ application rate. The improved variety provided significantly higher grain yield, $\mathrm{N}$ utilization efficiency and $\mathrm{N}$ use efficiency for grain yield (NUEGY) when $\mathrm{N}$ was applied $1 / 4$ at planting, $1 / 2$ at mid-tillering, and $1 / 4$ at anthesis. Variations in NUEGY were explained more by the variations in $\mathrm{N}$ uptake efficiency. Harvest index contribution to NUEGY was higher for the local variety. Although NUE significantly decreased with increasing $\mathrm{N}$ rates, yield response of the varieties did not plateau out.
\end{abstract}

Keywords: Grain yeild, protein, variety, uptake, utilization, biomass production 


\section{Introduction}

Wheat is one of the most important cereal crops globally and is a staple food for about one third of the world's population (Hussain et al., 2002). In Ethiopia, it is grown annually on 1.68 million ha with a total production of 3.08 million tons which makes the country the largest wheat producer in sub-Saharan Africa (CSA, 2010). Wheat provides more protein than any other cereal crops (Iqtidar et al., 2006). However, the global challenge for wheat nutrition is to increase grain yield while maintaining its protein (Tilman et al., 2002). Wheat yield and end-use quality depend upon the environment, genotype, and their interactions. Low soil fertility, especially nitrogen $(\mathrm{N})$ deficiency, is one of the major constraints limiting wheat production in Ethiopian Highlands (Tanner et al., 1993; Teklu and Hailemariam, 2009). Thus, increased usage of $\mathrm{N}$ fertilizer is considered to be a primary means of increasing wheat grain yield and protein content in these areas.

High levels of $\mathrm{N}$ supply results in a higher protein content, but increased efficiency of utilization is realized when concentration in the kernels increases and grain yield remains stable (Ortiz-Monasterio et al., 1997). Reports have shown that about $50 \%$ of applied $\mathrm{N}$ fertilizer remains unavailable to a crop due to $\mathrm{N}$ losses (Zafar and Muhammad, 2007). Legg and Meisinger (1982) also reported that not more than 50 to $60 \%$ of applied $\mathrm{N}$ is usually recovered under average field conditions, and efficient timing and placement of $\mathrm{N}$ could increase recovery of applied $\mathrm{N}$ up to 70 or to $80 \%$. In Ethiopia, erratic seasonal rainfall, inadequate availability of other nutrients, nitrate leaching during the short but heavy rainy seasons, ammonia volatilization and continuous removal in the cereal monocropping systems of the highlands may be the major factors that result in inefficient use of $\mathrm{N}$ fertilizer.
Proper $\mathrm{N}$ application timing and rates are critical for meeting crop needs, and indicate considerable opportunities for improving N use efficiency (NUE) (Dhugga and Waines, 1989; Blankenau et al., 2002). Growth stage of plants at the time of application determines NUE. Reports have shown that split $\mathrm{N}$ application in the later stages was effective in attaining higher $\mathrm{N}$ uptake efficiency (Kumari et al., 2000; Ashraf and Azam, 1998). NUE, grain yield produced per unit of $\mathrm{N}$ supply, is a complex trait comprising $\mathrm{N}$ uptake efficiency (NUPE) and N utilization efficiency (NUTE) (Moll et al., 1982; Ortiz-Monastero et al., 1997). NUPE reflects the ability of the plants in obtaining $\mathrm{N}$, while NUTE reflects the efficiency with which the crop utilizes $\mathrm{N}$ in the plant for the synthesis of grain yield. Tran and Tremblay (2000) reported that wheat NUPE was lower in the early applications at planting and tillering than application in the later crop growth stage. The amount of economic yield, therefore, increased by increasing NUPE and NUTE through efficient $\mathrm{N}$ application that decreases $\mathrm{N}$ losses from the soil-plant system (Muurinen, 2007).

Cultivars can differ in NUE as a result of differences in the absorption of nitrate (Rodgers and Barneix, 1988) and N remobilization (Van Sanford and MacKown, 1986). However, improved varieties are often developed without considering their ability to grow and yield under low soil nutrient status, and have been selected for high yields under high nutrient input conditions (Wissum et al., 2009). Feil (1992) indicated that varieties producing large amounts of biomass seemed to have more NUPE, which could decrease NUTE thereby also decreasing total NUE of modern varieties. Genetic variation highly influences NUTE (Singh and Arora, 2001), which particularly depends on harvest index (HI) and $\mathrm{N}$ biomass pro- 
duction efficiency (NBPE) (Ortiz-Monasterio et al., 1997). However, selection for higher HI may reduce the $\mathrm{N}$ storage capacity of the grain, since reduction in protein has been associated with high NUTE (Ortiz-Monasterio et al., 1997; Feil, 1997). On the other hand, reports have shown that NBPE has remained more or less unchanged during genetic improvement (Ortiz-Monasterio et al., 1997).

In Ethiopia, wheat is grown during the high rainfall season and losses of applied $\mathrm{N}$ through leaching may be decreased through proper rate and timing of $\mathrm{N}$ application. Limited research has been done on the effects of $\mathrm{N}$ rate and time of application in relation to genetic variations for NUE. Such studies may give a clue for enhancing grain yield and protein content of the crop through manipulating rates as well as timings of $\mathrm{N}$ application and/or plant breeding. Hence, this study was initiated to study the variations in NUE traits, and their association with grain yield and protein content of local and improved bread wheat varieties under different $\mathrm{N}$ rates and time of applications.

\section{Materials and Methods}

\subsection{Description of the experimental site}

The experiment was conducted at Adaba (located at $7^{\circ} 01^{\prime}$ N, 39²4' E), West Arsi zone of Oromia Region, during the 2010 main cropping season. The elevation ranges from 2300 to 2600 m.a.s.l and the area is characterized by mono-modal rainfall. The area is known for its extensive wheat production and often referred to as "the wheat grain belt of the country".

Weather data recorded at the experimental site indicated moderate annual rainfall across the years and distribution during the cropping season. The area received an annual rainfall of $891 \mathrm{~mm}$ during the cropping season (January-December, 2010) which was higher than the mean annual rainfall of the previous sixteen years. Mean maximum and minimum temperatures recorded at the station during the season were $23.8^{\circ} \mathrm{C}$ and $8.2^{\circ} \mathrm{C}$, respectively. High amounts of rainfall occur from June (planting month) to August (month of second split $\mathrm{N}$ application) of the cropping season. Rainfall of $113 \mathrm{~mm}$ was received in the month of September when the third split of $\mathrm{N}$ was applied.

\subsection{Treatments and experimental design}

The treatments consisted of four levels of nitrogen (30, 60, 90 and $\left.120 \mathrm{~kg} \mathrm{~N} \mathrm{ha}^{-1}\right)$, two bread wheat varieties and three timings of $\mathrm{N}$ application. The two bread wheat varieties [(Madda Walabu (HAR-1480) and Hollandi (local)] were selected based on differences in their morphological characteristics and yield potential. Madda Walabu is a CIMMYT origin semidwarf improved variety while Hollandi is a local variety which is also used for crossing in the breeding programme. Madda Walabu is high yielding, well adapted and widely grown in the area both by smallholder farmers and large scale commercial producers. The timings of $\mathrm{N}$ application were adjusted according to Zadoks decimal growth stage for wheat (Zadoks et al., 1974) at the time when moisture is available for nutrient dissolution and absorption. Accordingly, the timings were adjusted as: $T_{1}=1 / 2$ dose at planting and $1 / 2$ dose at mid-tillering, $T_{2} 1 / 4$ dose at planting, $1 / 2$ dose at mid-tillering and $1 / 4$ dose at anthesis and $\mathrm{T}_{3}=$ $1 / 3$ dose at planting, $1 / 3$ dose at mid-tillering and $1 / 3$ dose at anthesis. Two additional treatments of $0 \mathrm{~kg} \mathrm{~N}$ $\mathrm{ha}^{-1}$ (controls), one for each variety, were included for the determination of NUE traits.

Consequently, the experiment was laid out in randomized complete block design (RCBD) with factorial arrangements of $4 \times 2 \times 3=24$ treatment combinations together with the 2 controls making a total of 26 treatments and replicated three times. The size of each plot was $2.2 \mathrm{~m} \mathrm{x} 3.0 \mathrm{~m}\left(6.6 \mathrm{~m}^{2}\right)$ and the distance 
between the plots and blocks were kept at $0.5 \mathrm{~m}$ and 1 $\mathrm{m}$ apart, respectively. Each plot consisted of 11 rows. The net central unit areas of each plot consisting of 7 central rows of $1.5 \mathrm{~m}$ length each $\left(2.1 \mathrm{~m}^{2}\right)$ were used for data measurements.

\subsection{Experimental procedures}

\section{Field activities and treatment application}

All field activities were carried out following the standard production practices. Seeds were sown by uniformly drilling in to rows at the recommended rate of $150 \mathrm{~kg} \mathrm{ha}{ }^{-1}$. N fertilizer in the form of urea (46\% $\mathrm{N})$ and phosphate fertilizer in the form of triple super phosphate (TSP) $\left(46 \% \mathrm{P}_{2} \mathrm{O}_{5}\right)$ were used for the study. Phosphate fertilizer at the recommended rate of $46 \mathrm{~kg} \mathrm{P}_{2} \mathrm{O}_{5} \mathrm{ha}^{-1}$ was applied equally to all plots by surface broadcasting and mixing with the soil at planting. Similarly, for the $\mathrm{N}$ application at planting urea was broadcasted and incorporated into the soil. The second and third $\mathrm{N}$ fertilizer applications as dry urea were done by top-dressing at the specified Zadoks growth stages. All broad leaf and grass weeds were removed by hand weeding. Additionally, weeding of late-emerging weeds was done to avoid competition with the crop plants for applied N. In order to avoid damage and variability due to outbreak of rust disease which often occur in the area, fungicide (Tilt $250 \mathrm{EC}$ ) was applied at the rate of $0.5 \mathrm{~L} \mathrm{ha}^{-1}$ immediately at the start of disease appearance.

\section{Soil sampling and analysis}

One composite soil sample per replication, each made from five sub-samples, was collected from the depth of $0-30 \mathrm{~cm}$ before planting. The samples were airdried, ground using a pestle and a mortar and allowed to pass through a $2 \mathrm{~mm}$ sieve. The samples were ana- lyzed for selected physico-chemical properties mainly organic carbon, total $\mathrm{N}$, soil $\mathrm{pH}$, available phosphorus $(\mathrm{P})$, cation exchange capacity (CEC) and textural analysis using standard laboratory procedures.

Organic carbon content was determined by the volumetric method (Walkley and Black, 1934) as described in Food and Agriculture Organization of the United Nations (FAO) guide to laboratory establishment for plant nutrient analysis (FAO, 2008) using $1.0 \mathrm{~g}$ of the prepared soil sample. Total soil $\mathrm{N}$ was analyzed by Micro-Kjeldahl digestion method with sulphuric acid (Jackson, 1962). The pH of the soil was determined according to FAO (2008) using 1:2 (weight/volume) soil sample to $\mathrm{CaCl}_{2}$ solution $(0.01$ $\mathrm{M})$ ratio using a glass electrode attached to a digital $\mathrm{pH}$ meter. CEC was measured after saturating the soil with $1 \mathrm{M}$ ammonium acetate $\left(\mathrm{NH}_{4} \mathrm{OAc}\right)$ and displacing it with 1M NaOAc (Chapman, 1965). Available $\mathrm{P}$ was extracted by the Olsen method, and $\mathrm{P}$ analysed with a spectrophotometer (Olsen et al., 1954). Particle size distribution was done by hydrometer method according to FAO (2008).

\section{Straw nitrogen and grain protein analysis}

Straw N concentration was determined by MicroKjeldahl digestion method as indicated in FAO guide to laboratory establishment for plant nutrient analysis (FAO, 2008). At maturity representative samples of non-grain above ground plant parts (stems, leaves and chaff) were obtained from the central unit areas of 2.1 $\mathrm{m}^{2}$. The plant samples were washed with distilled water, oven dried at $70{ }^{\circ} \mathrm{C}$ to a constant weight and the dry weight measured using an electronic balance. The samples were ground by a rotor mill and allowed to pass through a $0.5 \mathrm{~mm}$ sieve to prepare a sample of $10 \mathrm{~g}$. For the digestion with $\mathrm{H}_{2} \mathrm{SO}_{4}(0.1 \mathrm{~N})$ containing digestion mixture (10 parts potassium sulphate and 1 part copper sulphate), $1 \mathrm{~g}$ of each treatment's ground 
sample were used. Likewise, total grain $\mathrm{N}$ contents of treated and untreated plots were estimated from $1 \mathrm{~g}$ dry flour samples by digestion method of Micro-Kjeldahl's apparatus according to American Association of Cereal Chemists (AACC) (AACC, 2000).

\subsection{Data measurements}

Grain yield and protein content

Grain Yield ( $\left.\mathrm{kg} \mathrm{ha}^{-1}\right)$ :- It was measured from the harvested central unit areas of $2.1 \mathrm{~m}^{2}$. The samples were cleaned following harvesting and threshing, weighed using an electronic balance and adjusted to $12.5 \%$ moisture content.

Grain Protein Concentration (\%):- the protein content of flour dry samples taken from the harvested grain yields of each treatment was calculated as \% protein $=\% N x 5.7$ (AACC, 2000)

\section{Nitrogen use efficiency traits}

Total $\mathrm{N}$ in the straw and grain samples were used to analyze $\mathrm{N}$ use efficiency and its component traits according to an expanded model of Moll et al. (1982) and Ortiz-Monasterio et al. (1997).

N Uptake Efficiency (\%) $=\frac{N t f\left(k g h a^{-1}\right)-N t c\left(k g h a^{-1}\right)}{N s\left(k g h a^{-1}\right)} \times 100$

Where, Ntf = total above-ground $N$ content at maturity of fertilized treatment

Ntc $=$ total above-ground $N$ content at maturity of control treatment

$N s=N$ supplied

$\mathbf{N}$ biomass Production
Efficiency $\left(\mathbf{k g ~ k g}^{-1} \mathbf{N}\right)=\frac{T D f\left(k g h a^{-1}\right)-T D W c\left(k g h a^{-1}\right)}{N t f\left(k g h a^{-1}\right)-N t c\left(k g h a^{-1}\right)}$

Where, $T D W f=$ total dry weight of fertilized treatment $T D W c=$ total dry weight of control treatment

\section{$\mathbf{N}$ Utilization
Efficiency $\left(\mathbf{k g ~ k g}^{-1} \mathbf{N}\right)=\begin{aligned} & \text { Harvest index } x N \text { biomass } \\ & \text { production efficiency }\end{aligned}$}

Where, GDWf = grain dry weight of fertilized treatment

$G D W c=$ grain dry weight of control treatment

$\mathbf{N}$ Use Efficiency
grain yield

$=\frac{G D W f\left(k g h a^{-1}\right)-G D W c\left(k g h a^{-1}\right)}{N s\left(k g h a^{-1}\right)}$

$$
\begin{gathered}
\mathbf{N} \text { Use Efficiency } \mathbf{y r a i n}_{\text {protein }}=\frac{G N Y f\left(k g h a^{-1}\right)-G N Y c\left(k g h a^{-1}\right)}{N s\left(k g h a^{-1}\right)} \\
\text { N Harvest Index }=\frac{G N Y\left(k g h a^{-1}\right)}{N t\left(k g h a^{-1}\right)}
\end{gathered}
$$

\subsection{Statistical analysis}

Analysis of the contributions of component traits to the resultant NUE trait were carried out as presented by Moll et al. (1982) and Dhugga and Waines (1989). If $Y_{n}$ is the log of a resultant trait and $X_{1 n}, X_{2 n}, X_{3 n}, X_{4 n}$ the logs of component traits at the $n^{\text {th }} \mathrm{N}$ level, then taking logarithms of these expressions yields the following identities:

$$
\begin{aligned}
& \mathrm{Y}_{1}=\mathrm{X}_{1}+\mathrm{X}_{2}+\mathrm{X}_{3} \\
& \mathrm{Y}_{2}=\mathrm{X}_{4}+\mathrm{X}_{2}+\mathrm{X}_{3}
\end{aligned}
$$

in which $Y_{1}=\log (N U E G Y), Y_{2}=\log (N U E P Y), X_{1}=$ $\log (G D W / T D W), \quad X_{2}=\log (N B P E), \quad X_{3}=\log (N U P E)$, $X_{4}=\log (G N Y / T D W)$.

The sum of cross products divided by the sum of squares of $Y_{1}$ and $Y_{2}$ at $n^{\text {th }} \mathrm{N}$ level, i.e., $\sum X_{\mathrm{i} n} Y_{n} / \sum Y_{n}^{2}$ represent the net contributions of each component traits to the dependent trait both directly and indirectly through the other variables. This can also be expressed as: $\sum X_{\mathrm{i} n} Y_{n} / \sum Y_{n}^{2}=\left(\mathrm{r}_{\mathrm{XinYn}}\right)\left(\mathrm{S}_{\mathrm{Xin}} / \mathrm{S}_{\mathrm{Yn}}\right)$, where $\mathrm{r}_{\mathrm{XinYn}}$ is a correlation coefficient between $X_{\text {in }}$ and $Y_{n}$, and $\mathrm{S}_{\mathrm{Xin}}$ and $\mathrm{S}_{\mathrm{Yn}}$ are the standard deviations for $\mathrm{X}_{\mathrm{in}}$ and $\mathrm{Y}_{\mathrm{n}}$, 
respectively. This analysis describes the net contribution of each component variable, both directly and indirectly through the other variable.

Analyses of variances for the data measured were conducted using the SAS GLM procedure. The significance differences between treatments mean values of each characteristic were computed using Duncan's Multiple Range Tests. Pearson's correlation analysis was done using Minitab software to determine associations between selected traits.

\section{Results and discussion}

\subsection{Soil physico-chemical properties}

Selected physico-chemical properties were analysed for composite surface soil $(0-30 \mathrm{~cm})$ samples collected from each replication before planting. The results indicated that texture of the soil in the experimental site is dominated by clay (sand $14 \%$, silt $21 \%$ and clay $64 \%$ ). According to the soil textural class determination triangle, soil of the experimental site was found to be clay. High clay content may indicate the better water and nutrient holding capacity of the soil in the experimental site.

The soil sample had marginal available P (13.26 $\mathrm{ppm}$ ) which indicates that some $\mathrm{P}$ fertilizer is required for optimum crop growth and yield (FAO, 2008). The soil reaction of the experimental site was nearly neutral ( $\mathrm{pH}=6.9)$. According to FAO (2008) suitable $\mathrm{pH}$ for most crops is between 6.5 and 7.5 where $\mathrm{N}$ availability is optimum.Percent organic carbon content of the soil was $2.17 \%$. The result showed that, according to Roy et al. (2006), the soil had low organic matter content $(3.74 \%)$ indicat- ing low potential of a soil to supply $\mathrm{N}$ to plants as organic matter can be used as an index of $\mathrm{N}$ availability. The CEC of the soil sample was high (53.2

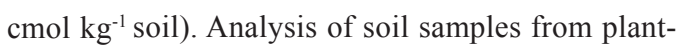
ing depth indicated very low level of total $\mathrm{N}(0.11 \%)$ indicating that the nutrient may be a limiting factor for wheat production in the area.

\subsection{Effects of nitrogen rate and time of application on grain yield}

Grain yield was significantly influenced by the main effects of $\mathrm{N}$ rate, time of $\mathrm{N}$ application and variety. It was also significantly $(p \leq 0.01)$ affected by the interactions of both $\mathrm{N}$ rate and time of application with variety. The mean values for the varieties across all $\mathrm{N}$ rates and times of application resulted in $24.1 \%$ higher grain yield of the improved variety (Madda Walabu) compared with the local variety (Hollandi; Table 1). The mean grain yield obtained from Madda Walabu at $0 \mathrm{~kg} \mathrm{~N} \mathrm{ha}{ }^{-1}$ was $31.6 \%$ higher than the mean grain yield of Hollandi at the same $\mathrm{N}$ application rate (data not shown). This indicates differences in the genetic background of the two varieties for yield potential. There were large yield reductions in the varietal controls compared with fertilized plots. Variety x N application rate indicated progressive increases in grain yields of the varieties with the increase in $\mathrm{N}$ rates in which the maximum yields for both varieties were attained at the highest level of $\mathrm{N}$ application $(120 \mathrm{~kg} \mathrm{~N}$ $\left.\mathrm{ha}^{-1}\right)$. However, the maximum yield of the Hollandi variety was $25.7 \%$ less than the maximum yield of Madda Walabu at the highest rate of $\mathrm{N}$ application, indicating the genetic differences in yield potential between the two varieties. 
Table 1. Grain yield of bread wheat as influenced by N rate and time of application at Adaba, 2010 main cropping season

\begin{tabular}{|c|c|c|c|}
\hline \multicolumn{4}{|c|}{ Grain yield $\left(\mathrm{kg} \mathrm{ha}^{-1}\right)$} \\
\hline Variety (V) & Madda Walabu & Hollandi & Mean \\
\hline \multicolumn{4}{|c|}{$\mathrm{N}$ rate $\left(\mathrm{kg} \mathrm{ha}^{-1}\right)(\mathrm{NR})$} \\
\hline 30 & $3818.51 \mathrm{~d}$ & $2975.03 f$ & 3396.77 \\
\hline 60 & $4037.65 \mathrm{c}$ & $3225.28 \mathrm{e}$ & 3631.47 \\
\hline 90 & $4594.37 b$ & $3337.02 \mathrm{e}$ & 3965.69 \\
\hline \multirow[t]{2}{*}{120} & $4880.13 \mathrm{a}$ & $3624.10 \mathrm{~d}$ & 4252.12 \\
\hline & V & NR & V x NR \\
\hline $\mathrm{SE} \pm$ & 38.03 & 53.78 & 76.06 \\
\hline $\mathrm{CD}$ & 108.30 & 153.10 & 216.50 \\
\hline \multicolumn{4}{|c|}{$\mathrm{N}$ application time (NT) } \\
\hline $1 / 2 \mathrm{P}$ and $1 / 2 \mathrm{MT}$ & $4275.90 \mathrm{~b}$ & $3277.44 \mathrm{c}$ & 3776.67 \\
\hline $1 / 4 \mathrm{P}, 1 / 2 \mathrm{MT}$ and $1 / 4 \mathrm{~A}$ & $4605.27 \mathrm{a}$ & $3292.54 \mathrm{c}$ & 3948.91 \\
\hline $1 / 3 \mathrm{P}, 1 / 3 \mathrm{MT}$ and $1 / 3 \mathrm{~A}$ & $4116.82 b$ & $3301.10 \mathrm{c}$ & 3708.96 \\
\hline \multirow[t]{2}{*}{ Mean } & 4332.66 & 3290.36 & \\
\hline & V & NT & V x NT \\
\hline $\mathrm{SE} \pm$ & 38.03 & 46.58 & 65.87 \\
\hline $\mathrm{CD}$ & 108.30 & 132.6 & 187.50 \\
\hline $\mathrm{CV}(\%)$ & & 5.99 & \\
\hline
\end{tabular}

Where, P, MT and A indicate N application at planting, mid-tillering and anthesis, respectively; NS = non-significant; $\mathrm{CD}=$ critical difference. Variable means followed by the same letters are not significantly different $(p \leq 0.05)$ according to Duncan's Multiple Range Tests.

The interaction effect between $\mathrm{N}$ application rate and variety showed significant yield increase for Madda Walabu with each increase in $\mathrm{N}$ application rate. On the other hand, yield of Hollandi was significantly influenced when $\mathrm{N}$ rate was changed between the two lower rates and the two higher rates, but was not affected when the rate changed between 60 and $90 \mathrm{~kg}$ $\mathrm{N} \mathrm{ha}^{-1}$. Grain yield of Hollandi at the highest $\mathrm{N}$ rate was lower than the yield of Madda Walabu obtained at zero $\mathrm{N}$ application. Time of $\mathrm{N}$ application interaction with variety also resulted in higher yield performance of Madda Walabu. N applications of $1 / 4$ at planting, $1 / 2$ at mid-tillering and $1 / 4$ at anthesis $(1 / 4 \mathrm{P}$, $1 / 2 \mathrm{MT}$ and $1 / 4 \mathrm{~A}$ ) resulted in significantly higher grain yield of Madda Walabu than the other $\mathrm{N}$ application timings. Thus, the yield of Madda Walabu obtained in the $\mathrm{N}$ application of $1 / 4 \mathrm{P}, 1 / 2 \mathrm{MT}$ and $1 / 4 \mathrm{~A}$ was significantly higher than the grain yield of the same variety obtained in the $\mathrm{N}$ application of $1 / 2$ dose at planting and $1 / 2$ dose at mid-tillering $(1 / 2 \mathrm{P}$ and $1 / 2 \mathrm{MT})$ by about $7.2 \%$.

Similarly, the grain yield of Madda Walabu obtained in the $\mathrm{N}$ application of $1 / 4 \mathrm{P}, 1 / 2 \mathrm{MT}$ and $1 / 4 \mathrm{~A}$ was significantly higher than the grain yields of the same 
variety obtained for the treatment of three time of $\mathrm{N}$ application with $1 / 3$ dose at planting, 1/3 dose at planting and $1 / 3$ dose at anthesis $(1 / 3 \mathrm{P}, 1 / 3 \mathrm{MT}$ and $1 / 3 \mathrm{~A}$ ) by about $10.2 \%$. Corroborating these results, Brian et al. (2007) reported higher grain yield when $\mathrm{N}$ was applied in three splits (at pre-planting, tillering and post anthesis) compared with two splits (at pre-planting and tillering) and one time application (at pre-planting). Tilahun Gelato et al. (2008), on the other hand, reported for wheat grown in southeastern Ethiopia that two split application of nitrogen at planting and tillering resulted in significantly higher grain yield.

Grain yield of Hollandi was unaffected by time of $\mathrm{N}$ application. The poor yield performance of the local variety under different $\mathrm{N}$ rates and time of application might be attributed to its low genetic potential for grain yield and its lower response to increased $\mathrm{N}$ availability. Higher response of Madda Walabu to different times of $\mathrm{N}$ application may indicate the growth and yield enhancing effect of applying $\mathrm{N}$ in three splits of $1 / 4 \mathrm{P}, 1 / 2 \mathrm{MT}$ and $1 / 4 \mathrm{~A}$. This may be attributed to the synchrony between the time of high need of the plant for $\mathrm{N}$ uptake and the time of availability of sufficient $\mathrm{N}$ in the soil at the specified growth stages. The yield enhancing effect of the three split applications of $\mathrm{N}$ on the variety may also be attributed to reduction in loss of nitrate by leaching during the wet growing season. Thus, at the time of high need for $\mathrm{N}$, the plant may have taken most of the nitrate from the soil, leaving less of it available for leaching by the percolating rain water. Reports indicated that in-season $\mathrm{N}$ application improves synchrony between crop demand and nutrient supply, especially in high rainfall areas where nitrate leaching is very common, was meant to enhance crop yield by improving $\mathrm{N}$ use efficiency (Zafar and Muhammad, 2007).

Grain yields for both varieties were higher at the highest level of $\mathrm{N}$ supply, indicating that the optimum yield may not have been realized as the response did not apparently plateau out. This means that the potential for further yield increases may have existed if higher $\mathrm{N}$ rates than $120 \mathrm{~kg} \mathrm{~N}^{-1}$ were applied. The highest rate of $\mathrm{N}$ fertilizer used in this experiment was almost twice as much as the $\mathrm{N}$ fertilizer rate recommended and used by farmers for wheat, which is 64 $\mathrm{kg} \mathrm{N} \mathrm{ha}^{-1}$ (Bekele et al., 2000). Currently, the average yield of the crop on farmers' fields in the area is 2.0 ton ha $^{-1}$ (CSA, 2010). Thus, there could be more potential to increase the productivity of both varieties if farmers use higher rates of $\mathrm{N}$ fertilizer with three split applications of $1 / 4 \mathrm{P}, 1 / 2 \mathrm{MT}$ and $1 / 4 \mathrm{~A}$. However, it has been reported that farmers in the area apply urea only once or twice (Bekele et al., 2000) contributing to lower yield of the crop. Perhaps a higher rate applied once would be wasted resulting in low economic benefits.

\subsection{Effects of nitrogen rate and time of application on grain protein content}

Grain protein content was found to be significantly influenced by $\mathrm{N}$ application rate, variety, $\mathrm{N}$ time of application and variety interaction with $\mathrm{N}$ time of application. However, the varieties did not differ in grain protein content under different $\mathrm{N}$ rates as variety interaction with $\mathrm{N}$ rate was non-significant. Grain protein content under different $\mathrm{N}$ application rates ranged from 12.40 to $13.09 \%$ (Table 2). The highest grain protein content (13.09\%) was obtained at the highest $\mathrm{N}$ rate $\left(120 \mathrm{~kg} \mathrm{~N} \mathrm{ha}^{-1}\right)$. Over all, grain protein content was found to increase with increasing $\mathrm{N}$ application rate. However, there were no differences in grain protein content at $\mathrm{N}$ rates of 30 to $90 \mathrm{~kg} \mathrm{ha}^{-1}$ and 90 to $120 \mathrm{~kg} \mathrm{ha}^{-1}$. Comparing the two varieties across all $\mathrm{N}$ rates and time of applications, the local variety had higher grain protein content (13.37\%). Under no $\mathrm{N}$ application, the local and improved varieties had grain protein contents of 
$12.06 \%$ and $11.80 \%$, respectively, indicating the difference in genetic backgrounds for the trait. Other authors, Brian et al. (2007), also reported an increase in grain protein concentration with $\mathrm{N}$ levels. Genetic variation for grain protein content in which older varieties provided higher protein was also reported by May et al. (1991). In contrast to the findings of this study, Cooper et al. (2001) reported significant effect of variety $\mathrm{x} \mathrm{N}$ rate interaction on wheat grain protein content.

Table 2. Grain protein content of bread wheat as influenced by N rate and time of applications at Adaba, 2010 main cropping season

\begin{tabular}{|c|c|c|c|}
\hline \multicolumn{4}{|c|}{ Grain protein content $(\%)$} \\
\hline Variety (V) & MaddaWalabu & Hollandi & Mean \\
\hline \multicolumn{4}{|c|}{$\mathrm{N}$ rate $\left(\mathrm{kg} \mathrm{ha}^{-1}\right)(\mathrm{NR})$} \\
\hline 30 & 11.96 & 12.84 & $12.40^{\mathrm{b}}$ \\
\hline 60 & 12.13 & 13.05 & $12.59^{\mathrm{b}}$ \\
\hline 90 & 12.14 & 13.54 & $12.84^{\mathrm{ab}}$ \\
\hline \multirow[t]{2}{*}{120} & 12.14 & 14.05 & $13.09^{\mathrm{a}}$ \\
\hline & $\mathrm{V}$ & NR & $V \times N R$ \\
\hline $\mathrm{SE} \pm$ & 0.12 & 0.16 & 0.23 \\
\hline $\mathrm{CD}$ & 0.33 & 0.47 & $\mathrm{NS}$ \\
\hline \multicolumn{4}{|c|}{$\mathrm{N}$ application time (NT) } \\
\hline $1 / 2 \mathrm{P}$ and $1 / 2 \mathrm{MT}$ & $11.93^{\mathrm{d}}$ & $12.78^{\mathrm{bc}}$ & 12.36 \\
\hline $1 / 4 \mathrm{P}, 1 / 2 \mathrm{MT}$ and $1 / 4 \mathrm{~A}$ & $12.30^{\mathrm{cd}}$ & $13.17^{\mathrm{b}}$ & 12.73 \\
\hline $1 / 3 \mathrm{P}, 1 / 3 \mathrm{MT}$ and $1 / 3 \mathrm{~A}$ & $12.04^{\mathrm{d}}$ & $14.15^{\mathrm{a}}$ & 13.10 \\
\hline \multirow[t]{2}{*}{ Mean } & $12.09^{\mathrm{b}}$ & $13.37^{\mathrm{a}}$ & \\
\hline & $\mathrm{V}$ & NT & V x NT \\
\hline $\mathrm{SE} \pm$ & 0.12 & 0.14 & 0.20 \\
\hline $\mathrm{CD}$ & 0.33 & 0.41 & 0.57 \\
\hline $\mathrm{CV}(\%)$ & & 5.88 & \\
\hline
\end{tabular}

Where, P, MT and A indicate N application at planting, mid-tillering and anthesis, respectively; NS = non-significant; $\mathrm{CD}=$ critical difference. Variable means followed by the same letters are not significantly different $(p \leq 0.05)$ according to Duncan's Multiple Range Tests.

The interaction of variety with $\mathrm{N}$ time of application showed significantly higher grain protein response of variety Hollandi when $\mathrm{N}$ was applied in three times equal split at planting, mid-tillering and anthesis. $\mathrm{N}$ applications of $1 / 2 \mathrm{P}$ and $1 / 2 \mathrm{MT}$, and $1 / 4 \mathrm{P}, 1 / 2 \mathrm{MT}$ and $1 / 4 \mathrm{~A}$ on Hollandi provided lower grain protein contents. Variety Madda Walabu, on the other hand, showed no significant variations in grain protein response to $\mathrm{N}$ application in the season. Mean values for grain protein indicated lower grain $\mathrm{N}$ concentration for protein formation of variety Madda Walabu compared to Hollandi in response to $\mathrm{N}$ application timings. In other studies, similar findings indicating lower grain protein concentration due to early $\mathrm{N}$ application at planting and tiller- 
ing compared to split $\mathrm{N}$ application up to anthesis were reported by Ayoub et al. (1995) and Brian et al. (2007).

\subsection{Effects of nitrogen rate and time of application on nitrogen use efficiency traits}

\section{Nitrogen uptake efficiency}

Nitrogen uptake efficiency (NUPE) was significantly influenced by $\mathrm{N}$ rate, time of $\mathrm{N}$ application as well as the interaction effect of variety and $\mathrm{N}$ rate. However, varietal differences in recovering the applied $\mathrm{N}$ and interaction with time of application were not signifi- cant. Mean values of NUPE in the $\mathrm{N}$ rate $\mathrm{x}$ variety interaction ranged from $41.08 \%$ at $120 \mathrm{~kg} \mathrm{~N}^{-1}$ and $72.33 \%$ at $30 \mathrm{~kg} \mathrm{~N}^{-1}$ (Table 3). The interaction effect indicated that NUPE of both varieties declined with increasing $\mathrm{N}$ rate. The highest NUPE of $72.33 \%$ for Madda Walabu and $67.98 \%$ for Hollandi were recorded at $30 \mathrm{~kg} \mathrm{~N} \mathrm{ha}^{-1}$. The lowest $\mathrm{N}$ uptake efficiencies, $41.08 \%$ for Madda Walabu and $45.91 \%$ for Hollandi, were recorded at the highest $\mathrm{N}$ rate $(120 \mathrm{~kg} \mathrm{~N}$ $\left.\mathrm{ha}^{-1}\right)$. Madda Walabu had shown sharp and significant decline in uptake efficiency with each increase in $\mathrm{N}$ rate while Hollandi resulted in no significant differences when the rate changed from 60 to $120 \mathrm{~kg} \mathrm{~N} \mathrm{ha}^{-1}$.

Table 3. Nitrogen uptake efficiency of bread wheat as influenced by $\mathrm{N}$ rate and time of applications at Adaba, 2010 main cropping season.

\begin{tabular}{|c|c|c|c|}
\hline \multicolumn{4}{|c|}{ N uptake efficiency (\%) } \\
\hline Variety (V) & Madda Walabu & Hollandi & Mean \\
\hline \multicolumn{4}{|c|}{$\mathrm{N}$ rate $\left(\mathrm{kg} \mathrm{ha}^{-1}\right)(\mathrm{NR})$} \\
\hline 30 & $72.33 \mathrm{a}$ & $63.63 b$ & 67.98 \\
\hline 60 & $53.47 \mathrm{c}$ & $51.49 \mathrm{~cd}$ & 52.48 \\
\hline 90 & $47.71 \mathrm{~d}$ & $46.55 d$ & 47.13 \\
\hline \multirow[t]{2}{*}{120} & $41.08 \mathrm{e}$ & $45.91 \mathrm{de}$ & 43.50 \\
\hline & V & NR & V x NR \\
\hline $\mathrm{SE} \pm$ & 0.91 & 1.28 & 1.82 \\
\hline $\mathrm{CD}$ & NS & 3.66 & 5.17 \\
\hline \multicolumn{4}{|c|}{$\mathrm{N}$ application time (NT) } \\
\hline $1 / 2 \mathrm{P}$ and $1 / 2 \mathrm{MT}$ & 48.15 & 48.54 & $48.34 b$ \\
\hline $1 / 4 \mathrm{P}, 1 / 2 \mathrm{MT}$ and $1 / 4 \mathrm{~A}$ & 58.41 & 53.58 & $55.99 \mathrm{a}$ \\
\hline $1 / 3 \mathrm{P}, 1 / 3 \mathrm{MT}$ and $1 / 3 \mathrm{~A}$ & 54.38 & 53.58 & $53.98 \mathrm{a}$ \\
\hline \multirow[t]{2}{*}{ Mean } & 53.65 & 51.90 & \\
\hline & V & NT & V x NT \\
\hline $\mathrm{SE} \pm$ & 0.91 & 1.11 & 1.57 \\
\hline $\mathrm{CD}$ & NS & 3.17 & NS \\
\hline $\mathrm{CV}(\%)$ & & 10.32 & \\
\hline
\end{tabular}

Where, $\mathrm{P}, \mathrm{MT}$ and A indicate $\mathrm{N}$ application at planting, mid-tillering and anthesis, respectively; NS = non-significant; $\mathrm{CD}=$ critical difference. Variable means followed by the same letters are not significantly different $(p \leq 0.05)$ according to Duncan's Multiple Range Tests 
Significant decline in NUPE for Hollandi occurred when the $\mathrm{N}$ rate was raised from 30 to $60 \mathrm{~kg} \mathrm{~N} \mathrm{ha}^{-1}$. The results showed that the Madda Walabu had significantly higher $\mathrm{N}$ uptake efficiency at the lower level of $\mathrm{N}$. However, the varieties did not significantly differ in recovering the applied $\mathrm{N}$ at higher rates, i.e., 60,90 and $120 \mathrm{~kg} \mathrm{~N} \mathrm{ha}^{-1}$. Corroborating these results, Moll et al. (1982), Ortiz-Monasterio et al. (1997), and Sinebo et al. (2004) also reported that $\mathrm{N}$ uptake efficiency was higher at lower rates of $\mathrm{N}$ application but drastically decreased with further increases in the rate of the nutrient. In-season application indicated higher uptake efficiency of $\mathrm{N}$ by the crop when the fertilizer was applied in three splits regardless of the amount of the dose at each time. Thus, compared to the two split $\mathrm{N}$ applications at planting and mid-tillering, the three split applications resulted in significantly higher uptake efficiencies. Compared to the NUPE of wheat plants grown with $\mathrm{N}$ applications $1 / 2 \mathrm{P}$ and $1 / 2 \mathrm{MT}$, the efficiency of wheat plants grown with $\mathrm{N}$ applications of $1 / 4 \mathrm{P}, 1 / 2 \mathrm{MT}$ and $1 / 4 \mathrm{~A}$ was superior by $13.7 \%$.

The result, generally, indicated a greater effect of $\mathrm{N}$ rate and application timing on NUPE, and less varietal differences for the trait. Similar efficiencies of the varieties across all $\mathrm{N}$ supply and in response to application timing might indicate the lack of genetic variability for the trait between them. Corroborating these results, Ortiz-Monasterio et al. (1997) and Tran and Tremblay (2000) also indicated lower NUPE in the early applications of $\mathrm{N}$ fertilizer at planting and tillering compared to applications in the later stage of crop growth. Wuest and Cassman (1992a) reported NUPE values of 30 to $55 \%$ when $\mathrm{N}$ was applied at planting and 55 to $80 \%$ when $\mathrm{N}$ was additionally applied at anthesis. The non-significant varietal difference for NUPE in this study is also in agreement with the findings of Moll et al. (1987) who reported less genetic variations and suggested that the trait would not be a breeding goal to modify. In contrast, how- ever, Van Sanford and MacKown (1986) and Dhugga and Waines (1989) reported that there were genetic variations among plants for $\mathrm{N}$ uptake efficiency.

Nitrogen biomass production and utilization efficiencies

Analysis of variance for $\mathrm{N}$ biomass production efficiency (NBPE) indicated highly significant influence $(p \leq 0.001)$ of $\mathrm{N}$ application rate and variety. The trait was not influenced by time of $\mathrm{N}$ application and the interaction effect of variety with both $\mathrm{N}$ rate and time of application. On the other hand, $\mathrm{N}$ utilization efficiency (NUTE) was significantly influenced by $\mathrm{N}$ rate, time of $\mathrm{N}$ application, and interaction of variety with time of $\mathrm{N}$ application. The varieties did not differ significantly in utilizing the total plant $\mathrm{N}$ for grain yield. The interaction effect of $\mathrm{N}$ rate with variety also indicated similar NUTE of the varieties at all rates of application.

$\mathrm{N}$ biomass production efficiency at different $\mathrm{N}$ rates ranged from 59.70 to $83.44 \mathrm{~kg} \mathrm{~kg}^{-1} \mathrm{~N}$ at the rates of 30 and $120 \mathrm{~kg} \mathrm{~N} \mathrm{ha}^{-1}$, respectively. The efficiency generally declined with the increasing rate of $\mathrm{N}$ application. Compared to $\mathrm{N}$ application rate of $30 \mathrm{~kg} \mathrm{~N}^{-1}$, the application rate of $120 \mathrm{~kg} \mathrm{~N}$ ha-1 $^{-1}$ resulted in $28.5 \%$ lower NBPE indicating higher biomass yield per unit of total plant $\mathrm{N}$ at the lower rate. Thus, the result indicated higher efficiency of the crop in exploiting total plant $\mathrm{N}$ for biomass yield when it was supplied by the lower $\mathrm{N}$ rate. Averaged over all $\mathrm{N}$ rates and time of application, Madda Walabu had 27.9\% higher biomass production per unit of total plant $\mathrm{N}$ compared with Hollandi. The result is in line with that of Roberts (2008), who indicated higher efficiency of $\mathrm{N}$ in biomass production under the application of lower levels of nitrogen. Van Sanford and MacKown (1986) reported N biomass production efficiency ranging from 66.5 to $91.4 \mathrm{~kg} \mathrm{~kg}^{-1}$ $\mathrm{N}$ for wheat genotypes supplied with different $\mathrm{N}$ rates. 
In-season $\mathrm{N}$ application of $1 / 4 \mathrm{P}, 1 / 2 \mathrm{MT}$ and $1 / 4 \mathrm{~A}$ resulted in significantly higher NBPE. Two times equal split applications at planting and mid-tillering, and three times equal split applications at planting, mid-tillering and anthesis, on the other hand, resulted in similar and significantly lower efficiency of $\mathrm{N}$ in biomass production. Consistent with these results, Jan et al. (2010) also reported higher efficiency of $\mathrm{N}$ biomass production in wheat when $\mathrm{N}$ was supplied in three splits (at planting, tillering and stem elongation) compared to single application at planting and two split applications at planting and tillering.

The mean value for NUTE under different $\mathrm{N}$ application rate ranged from $27.10 \mathrm{~kg} \mathrm{~kg}^{-1} \mathrm{~N}$ in the highest $\mathrm{N}$ rate to $39.27 \mathrm{~kg} \mathrm{~kg}^{-1} \mathrm{~N}$ in the lowest $\mathrm{N}$ rate. This indicates that the plant produced about $27 \mathrm{~kg}$ wheat grain yield per $1 \mathrm{~kg}$ of total plant $\mathrm{N}$ and about $39 \mathrm{~kg}$ wheat grain yield for every $\mathrm{kg} \mathrm{N}$ it had in the total biomass, respectively. Utilization efficiency of the total above ground plant $\mathrm{N}$ for grain yield at $30 \mathrm{~kg}$ $\mathrm{N} \mathrm{ha}^{-1}$ was higher by $31.0 \%$ compared with the efficiency obtained at $120 \mathrm{~kg} \mathrm{~N}^{-1}$. The efficiency significantly dropped when $\mathrm{N}$ application rate changed from 30 to $90 \mathrm{~kg} \mathrm{~N} \mathrm{ha}^{-1}$. However, mean comparison showed statistically similar NUTE between 60 and 90 $\mathrm{kg} \mathrm{N} \mathrm{ha}{ }^{-1}$ as well as between 90 and $120 \mathrm{~kg} \mathrm{~N} \mathrm{ha}^{-1}$. The decreases in efficiency of $\mathrm{N}$ utilization were 17.5, 8.4 and $8.6 \%$, respectively, when fertilizer application rates increased from 30-60, 60-90 and 90-120 kg N $\mathrm{ha}^{-1}$, respectively.

The result indicated higher dry matter partitioning to the grain per unit of total plant $\mathrm{N}$ under the application of lower $\mathrm{N}$ rates compared with the higher rates. In agreement with this result, Ortiz-Monasterio et al.
(1997) and Singh and Arora (2001) also reported significant influence of $\mathrm{N}$ application rate on NUTE in which the highest efficiencies were measured at the lowest application rate. Van Sanford and MacKown (1986) and (Sinebo et al., 2004) also found similar results in which they reported NUTE values of 29.343.9 and $31.8-48.3 \mathrm{~kg} \mathrm{~kg}^{-1} \mathrm{~N}$, respectively. Consistent with the results of the present study, Gouis et al. (2000) reported non-significant effect of variety as well as that of the interaction between $\mathrm{N}$ rate and genotype on NUTE. The non-significant varietal difference in this study, however, is in contrast to the findings of Dhugga and Waines (1989) and Singh and Arora (2001) who reported significant varietal differences on NUTE.

Nitrogen time of application $\mathrm{x}$ variety interaction resulted in significantly higher NUTE for Madda Walabu due to $\mathrm{N}$ application of $1 / 4 \mathrm{P}, 1 / 2 \mathrm{MT}$ and $1 / 4 \mathrm{~A}$. The variety, however, had lower NUTE when $\mathrm{N}$ was applied in two splits at planting and mid-tillering, which was statistically similar with the $\mathrm{N}$ utilization efficiency measured for the three times equal split application at planting, mid-tillering and anthesis. For Madda Walabu, N application of $1 / 4 \mathrm{P}, 1 / 2 \mathrm{MT}$ and $1 / 4 \mathrm{~A}$ resulted in $23.7 \%$ and $20.1 \%$ higher NUTE than the treatments of two times and the three times equal split applications, respectively.

Hollandi did not significantly respond to $\mathrm{N}$ time of application in terms of total plant $\mathrm{N}$ utilization for grain yield. This result confirm reports of Tran and Tremblay (2000) and Jan et al. (2010), who found lower NUTE in response to early $\mathrm{N}$ applications at planting and tillering compared with additional split application at anthesis. This result is also in agree- 
ment with that of Cooper et al. (2001) who reported significant variety $\mathrm{x} \mathrm{N}$ time of application interaction effects on NUTE.

Nitrogen harvest index, and nitrogen use efficiency for grain and protein yields

Non-significant effect of $\mathrm{N}$ rate, the interaction effects of variety $\mathrm{x} \mathrm{N}$ rate as well as variety $\mathrm{x} \mathrm{N}$ time of application were observed on $\mathrm{N}$ harvest index (NHI) while $\mathrm{N}$ time of application and variety main effects significantly influenced $(p \leq 0.01)$ the trait. $\mathrm{N}$ use efficiency for grain yield (NUEGY) was highly influenced by the main effects of $\mathrm{N}$ rate, $\mathrm{N}$ time of application, and variety. The trait was also highly influenced by the interaction effects of variety with both $\mathrm{N}$ rate and time of applications. There were significant effects of $\mathrm{N}$ rate and times of application as well as the interaction effect of $\mathrm{N}$ rate $\mathrm{x}$ variety on $\mathrm{N}$ use efficiency for protein yield (NUEPY). However, the varieties did not differ in NUEPY and no interaction effect of variety and $\mathrm{N}$ time of application was observed for this parameter.

The result indicated that application of different $\mathrm{N}$ levels did not influence the partitioning of total plant $\mathrm{N}$ in to the grain. Comparing the two varieties across all $\mathrm{N}$ rates and time of applications, Madda Walabu had $4.3 \%$ higher partitioning of total plant $\mathrm{N}$ in grain. The result is in line with the reports by Moll et al.
(1982) and Dhugga and Waines (1989) who reported genetic variations for NHI, suggesting that the trait is under genetic control. On the other hand, $\mathrm{N}$ application in the season indicated similar and significantly higher NHI in the three times $\mathrm{N}$ applications compared with two times application. $\mathrm{N}$ applications of $1 / 4 \mathrm{P}, 1 / 2 \mathrm{MT}$ and $1 / 4 \mathrm{~A}$ resulted in $5.8 \%$ higher total plant $\mathrm{N}$ partitioning in to the grain than the applications of $1 / 2 \mathrm{P}$ and $1 / 2 \mathrm{MT}$. The higher NHI in the three split $\mathrm{N}$ application in this study is consistent with the findings of Jan et al. (2010) who also reported higher index with the additional $\mathrm{N}$ application at anthesis.

$\mathrm{N}$ use efficiency for grain yield (NUEGY) in response to the interaction effect of $\mathrm{N}$ rate and variety ranged from $11.57 \mathrm{~kg} \mathrm{~kg}^{-1} \mathrm{~N}$ for the highest $\mathrm{N}$ rate to $29.51 \mathrm{~kg}$ grain $\mathrm{kg}^{-1} \mathrm{~N}$ for the lowest rate (Table 5). For both varieties, the result generally indicated a decrease in efficiency of $\mathrm{N}$ use for grain yield with increasing $\mathrm{N}$ fertilizer rate. Madda Walabu exhibited both high and low NUEGY under lower and higher $\mathrm{N}$ application rates, respectively, in which the efficiency was dropped by more than one-fold. For Hollandi, increasing $\mathrm{N}$ application rate from 30 to $120 \mathrm{~kg} \mathrm{~N}^{-1}$ decreased the NUEGY by $46.8 \%$. The result indicated efficient $\mathrm{N}$ use for grain yield when the crop was supplied with smaller amounts of $\mathrm{N}$ in which the overall efficiency of the improved variety was higher than that of the local variety. 
Table 4. Nitrogen biomass production and utilization efficiencies of bread wheat as influenced by $\mathrm{N}$ rate and time of applications at Adaba, 2010 main cropping season

\begin{tabular}{|c|c|c|c|c|c|c|}
\hline & NBPE $\left(\mathrm{kg} \mathrm{kg}^{-1} \mathrm{~N}\right)$ & & & NUTE $\left(\mathrm{kg} \mathrm{kg}^{-1} \mathrm{~N}\right.$ & & \\
\hline Variety (V) & Madda Walabu & Hollandi & Mean & Madda Walabu & Hollandi & Mean \\
\hline \multicolumn{7}{|c|}{ N rate $\left(\mathrm{kg} \mathrm{ha}^{-1}\right)(\mathrm{NR})$} \\
\hline 30 & 91.31 & 75.57 & $83.44 \mathrm{a}$ & 40.68 & 37.86 & $39.27 \mathrm{a}$ \\
\hline 60 & 87.05 & 58.33 & $72.69 \mathrm{~b}$ & 32.25 & 32.54 & $32.39 \mathrm{~b}$ \\
\hline 90 & 76.82 & 52.63 & $64.72 \mathrm{bc}$ & 30.83 & 28.49 & $29.66 \mathrm{bc}$ \\
\hline \multirow[t]{2}{*}{120} & 70.81 & 48.58 & $59.70 \mathrm{c}$ & 28.55 & 25.65 & $27.10 \mathrm{c}$ \\
\hline & $\mathrm{V}$ & NR & V x NR & $\mathrm{V}$ & NR & V x NR \\
\hline $\mathrm{SE} \pm$ & 2.07 & 2.92 & 4.13 & 0.76 & 1.08 & 1.53 \\
\hline $\mathrm{CD}$ & 5.88 & 8.32 & NS & NS & 3.08 & NS \\
\hline \multicolumn{7}{|c|}{$\mathrm{N}$ application time (NT) } \\
\hline $1 / 2 \mathrm{P}$ and $1 / 2 \mathrm{MT}$ & 81.19 & 58.37 & 69.78 & $29.54 b$ & $31.95 \mathrm{~b}$ & 30.74 \\
\hline $1 / 4 \mathrm{P}, 1 / 2 \mathrm{MT}$ and $1 / 4 \mathrm{~A}$ & 82.65 & 65.82 & 74.23 & $38.74 a$ & $31.44 \mathrm{~b}$ & 35.09 \\
\hline $1 / 3 \mathrm{P}, 1 / 3 \mathrm{MT}$ and $1 / 3 \mathrm{~A}$ & 80.66 & 52.15 & 66.41 & $30.96 b$ & $30.02 b$ & 30.49 \\
\hline \multirow[t]{2}{*}{ Mean } & $81.50 \mathrm{a}$ & $58.78 \mathrm{~b}$ & & 33.08 & 31.13 & \\
\hline & V & NT & V x NT & V & NT & $\mathrm{V} \times \mathrm{NT}$ \\
\hline $\mathrm{SE} \pm$ & 2.07 & 2.53 & 3.58 & 0.76 & 0.94 & 1.32 \\
\hline $\mathrm{CD}$ & 5.88 & NS & NS & NS & 2.66 & 3.77 \\
\hline $\mathrm{CV}(\%)$ & & 17.67 & & & 14.28 & \\
\hline
\end{tabular}

Where, P, MT and A indicate N application at planting, mid-tillering and anthesis, respectively; NS = non-significant; $\mathrm{CD}=$ critical difference. Variable means followed by the same letters are not significantly different $(p \leq 0.05)$ according to Duncan's Multiple Range Tests.

Table 5. Nitrogen harvest index, and $\mathrm{N}$ use efficiency for grain and protein yield of bread wheat as influenced by $\mathrm{N}$ rate and time of applications at Adaba, 2010 main cropping season.

\begin{tabular}{|c|c|c|c|c|c|c|c|c|c|}
\hline \multirow[b]{2}{*}{ Variety (V) } & \multicolumn{3}{|c|}{ NHI } & \multicolumn{3}{|c|}{ NUEGY (kg grain kg $\left.{ }^{-1} \mathbf{N}\right)$} & \multicolumn{3}{|c|}{ NUEPY $\left(\mathrm{kg} \mathrm{kg}^{-1} \mathrm{~N}\right)$} \\
\hline & $\begin{array}{c}\text { Madda } \\
\text { Walabu }\end{array}$ & Hollandi & Mean & $\begin{array}{c}\text { Madda } \\
\text { Walabu }\end{array}$ & Hollandi & Mean & $\begin{array}{c}\text { Madda } \\
\text { Walabu }\end{array}$ & Hollandi & Mean \\
\hline \multicolumn{10}{|c|}{$\mathrm{N}$ rate $\left(\mathrm{kg} \mathrm{ha}^{-1}\right)(\mathrm{NR})$} \\
\hline 30 & 0.71 & 0.64 & 0.67 & $29.51 \mathrm{a}$ & $24.08 b$ & 26.80 & $0.63 \mathrm{a}$ & $0.54 b$ & 0.58 \\
\hline 60 & 0.70 & 0.67 & 0.69 & $17.16 \mathrm{c}$ & $16.45 \mathrm{c}$ & 16.81 & $0.41 \mathrm{~cd}$ & $0.45 \mathrm{c}$ & 0.43 \\
\hline 90 & 0.68 & 0.66 & 0.67 & $14.73 \mathrm{~cd}$ & $13.19 \mathrm{de}$ & 13.96 & $0.34 d$ & $0.37 \mathrm{~d}$ & 0.35 \\
\hline \multirow[t]{2}{*}{120} & 0.66 & 0.65 & 0.66 & $11.57 \mathrm{e}$ & $12.80 \mathrm{de}$ & 12.18 & $0.26 \mathrm{e}$ & $0.34 \mathrm{~d}$ & 0.30 \\
\hline & V & NR & V x NR & V & NR & $\mathrm{V} \times \mathrm{NR}$ & V & NR & $\mathrm{V} \times \mathrm{NR}$ \\
\hline
\end{tabular}


Continued....

\begin{tabular}{|c|c|c|c|c|c|c|c|c|c|}
\hline \multirow[b]{2}{*}{ Variety (V) } & \multicolumn{3}{|c|}{ NHI } & \multicolumn{3}{|c|}{ NUEGY (kg grain kg-1 $\mathbf{N})$} & \multicolumn{3}{|c|}{ NUEPY $\left(\mathrm{kg} \mathrm{kg}^{-1} \mathrm{~N}\right)$} \\
\hline & $\begin{array}{l}\text { Madda } \\
\text { Walabu }\end{array}$ & Hollandi & Mean & $\begin{array}{l}\text { Madda } \\
\text { Walabu }\end{array}$ & Hollandi & Mean & $\begin{array}{c}\text { Madda } \\
\text { Walabu }\end{array}$ & Hollandi & Mean \\
\hline $\mathrm{SE} \pm$ & 0.007 & 0.010 & 0.014 & 0.48 & 0.68 & 0.96 & 0.013 & 0.019 & 0.027 \\
\hline $\mathrm{CD}$ & 0.020 & NS & NS & 1.36 & 1.92 & 2.72 & NS & 0.054 & 0.076 \\
\hline \multicolumn{10}{|c|}{$\mathrm{N}$ application time (NT) } \\
\hline $1 / 2 \mathrm{P}$ and $1 / 2 \mathrm{MT}$ & 0.67 & 0.63 & $0.65 b$ & $14.35 \mathrm{c}$ & $16.51 b c$ & 15.43 & 0.35 & 0.36 & $0.35 b$ \\
\hline $\begin{array}{l}1 / 4 \mathrm{P}, 1 / 2 \mathrm{MT} \text { and } \\
1 / 4 \mathrm{~A}\end{array}$ & 0.72 & 0.67 & $0.69 \mathrm{a}$ & $22.80 \mathrm{a}$ & $17.29 \mathrm{~b}$ & 20.04 & 0.47 & 0.45 & $0.46 \mathrm{a}$ \\
\hline $\begin{array}{l}1 / 3 \mathrm{P}, 1 / 3 \mathrm{MT} \text { and } \\
1 / 3 \mathrm{~A}\end{array}$ & 0.68 & 0.67 & $0.68 \mathrm{a}$ & $17.59 b$ & $16.09 \mathrm{bc}$ & 16.84 & 0.41 & 0.46 & $0.43 \mathrm{a}$ \\
\hline \multirow[t]{2}{*}{ Mean } & $0.69 \mathrm{a}$ & $0.66 \mathrm{~b}$ & & 18.24 & 16.63 & & 0.41 & 0.42 & \\
\hline & V & NT & $\mathrm{V} \times \mathrm{NT}$ & V & NT & $\mathrm{V} \times \mathrm{NT}$ & V & NT & $\mathrm{V} \times \mathrm{NT}$ \\
\hline $\mathrm{SE} \pm$ & 0.007 & 0.009 & 0.012 & 0.48 & 0.58 & 0.83 & 0.013 & 0.016 & 0.023 \\
\hline $\mathrm{CD}$ & 0.020 & 0.024 & NS & 1.36 & 1.67 & 2.36 & NS & 0.046 & NS \\
\hline CV (\%) & & 6.21 & & & 16.44 & & & 19.19 & \\
\hline
\end{tabular}

Where, P, MT and A indicate N application at planting, mid-tillering and anthesis, respectively; NS = non-significant; $\mathrm{CD}=$ critical difference. Variable means followed by the same letters are not significantly different $(p \leq 0.05)$ according to Duncan's Multiple Range Tests

For both varieties, sharp decreases in NUEGY when $\mathrm{N}$ application rate increased from 30 to $60 \mathrm{~kg} \mathrm{~N}^{-1}$ were occurred. Madda Walabu showed similar NUEGY at the applications of 60 and $90 \mathrm{~kg} \mathrm{~N} \mathrm{ha}^{-1}$, even though, the efficiency significantly decreased as the rate increased from 90 to $120 \mathrm{~kg} \mathrm{~N} \mathrm{ha}^{-1}$. On the other hand, Hollandi showed significant decreases in NUEGY when $\mathrm{N}$ application rate increased from 60 to $90 \mathrm{~kg} \mathrm{~N}^{-1}$ but with similar efficiency in the 90 and $120 \mathrm{~kg} \mathrm{~N} \mathrm{ha}{ }^{-1}$. The result is consistent with that of Dhugga and Waines (1989), Ortiz-Monasterio et al. (1997) and Roberts (2008) who found significant decreases in NUEGY with increasing rates of $\mathrm{N}$ application. Furthermore, significant genetic variations for NUEGY were also reported by Moll et al. (1982),
Dhugga and Waines (1989) and Feil (1992) in which the improved varieties showed higher efficiency.

Variety $\mathrm{x} \mathrm{N}$ time of application interaction showed significantly higher NUEGY of Madda Walabu when $\mathrm{N}$ was supplied in three times applications of $1 / 4 \mathrm{P}, 1 / 2 \mathrm{MT}$ and $1 / 4 \mathrm{~A}$. The mean value for the trait due to the two equal split $\mathrm{N}$ application at planting and mid-tillering was significantly lower compared with the three times applications. Three times equal split application of $\mathrm{N}$ at planting, mid-tillering and anthesis for variety Madda Walabu resulted in intermediate NUEGY. Compared with the other timings, $\mathrm{N}$ applications of $1 / 4 \mathrm{P}, 1 / 2 \mathrm{MT}$ and $1 / 4$ resulted in 37.1 and $22.9 \%$, respectively, higher NUEGY of Madda Walabu. 
On the other hand, NUEGY of variety Hollandi was not significantly changed by in-season $\mathrm{N}$ application. In other studies, lower NUEGY in the early $\mathrm{N}$ application at planting and tillering was reported by Blankenau et al. (2002) compared with the additional split $\mathrm{N}$ applications applied at the later crop stage.

The efficiency of using applied $\mathrm{N}$ from 90 and $120 \mathrm{~kg} \mathrm{~N} \mathrm{ha}^{-1}$ for protein yield was, however, statistically similar. Compared to $120 \mathrm{~kg} \mathrm{~N} \mathrm{ha}^{-1}$, application of $30 \mathrm{~kg} \mathrm{~N} \mathrm{ha}^{-1}$ resulted in $58.8 \%$ higher NUEPY of Hollandi. Under the applications of 60 and $90 \mathrm{~kg} \mathrm{~N}$ $\mathrm{ha}^{-1}$, the two varieties had comparable performances for NUEPY. In other studies, Baenziger (1994b) reported higher NUEPY under lower $\mathrm{N}$ application rates with no genetic variations for the trait. This result, however, contrasts with that of Van Sanford and MacKown (1986) who found significant genotypic variation for NUEPY.

Nitrogen applications of $1 / 4 \mathrm{P}, 1 / 2 \mathrm{MT}$ and $1 / 4 \mathrm{~A}$, and $1 / 3 \mathrm{P}, 1 / 3 \mathrm{MT}$ and $1 / 3 \mathrm{~A}$ resulted in higher NUEPY. The two equal split applications at planting and mid-tillering, however, produced significantly lower NUEPY. The result indicated the importance of higher proportion of $\mathrm{N}$ application at mid-tillering and additional lower proportions at anthesis for enhanced efficiency of $\mathrm{N}$ use from applied $\mathrm{N}$ for protein synthesis. The result is in agreement with the findings of Baenziger (1994b) who reported that additional late $\mathrm{N}$ application during grain filling resulted in higher NUEPY.

\subsection{Contributions of the component traits to NUE efficiency}

The result indicated that, under all $\mathrm{N}$ application rates, the variation in NUPE explained most of the variation in NUEGY of both varieties in which the higher contributions were observed in the lowest rates. On the other hand, NBPE had little account for the variations in NUEGY of the varieties (Table 6). For Madda Walabu, application of 30 to $90 \mathrm{~kg} \mathrm{~N}$ $\mathrm{ha}^{-1}$ resulted in similar contribution of NUPE $(58 \%)$ to the resultant NUEGY while the contribution at the highest rate was reduced by $1 \%$. For the same variety (averaged over all $\mathrm{N}$ levels), HI, NBPE and NUPE explained $25 \%, 18 \%$ and $58 \%$ of the variations in NUEGY respectively. The relative contribution of NUTE (NBPE + HI) to NUEGY of the variety across all $\mathrm{N}$ rates was lower by $15 \%$ compared with the contribution made by NUPE. NUPE also accounted for higher variation in NUEPY of the variety in which the contribution was similar under the two lower $\mathrm{N}$ rates and then progressively declined with the increasing $\mathrm{N}$ rates. The proportion of GNY to TDW contributed to $50 \%$ of the variation in NUEPY.

Table 6. Relative contributions of the component traits to the sum of squares ( $\left.\sum \mathrm{XinYn} / \mathrm{Yn} 2\right)$ of the resultant traits (NUEGY and NUEPY) of bread wheat supplied with different $\mathrm{N}$ rates at Adaba, 2010 main cropping season

\begin{tabular}{lcccccccccccc}
\hline & Variety & \multicolumn{4}{c}{ Madda Walabu } & \multicolumn{5}{c}{ Hollandi } \\
\cline { 2 - 12 } & $\begin{array}{l}\text { N rate } \\
\text { (kg/ha) }\end{array}$ & $\mathbf{3 0}$ & $\mathbf{6 0}$ & $\mathbf{9 0}$ & $\mathbf{1 2 0}$ & Mean & $\mathbf{3 0}$ & $\mathbf{6 0}$ & $\mathbf{9 0}$ & $\mathbf{1 2 0}$ & Mean \\
\hline Traits & Log & & & & & & & & & \\
\hline $\begin{array}{l}\text { NUEGY (GDW/ } \\
\text { NS) }\end{array}$ & Y1 & - & - & - & - & - & - & - & - & - & - \\
HI (GDW/TDW) & $\mathrm{X} 1$ & 0.25 & 0.25 & 0.24 & 0.24 & 0.25 & 0.31 & 0.30 & 0.30 & 0.29 & 0.30
\end{tabular}


Continued....

\begin{tabular}{lcccccccccccc}
\hline & Variety & \multicolumn{4}{c}{ Madda Walabu } & \multicolumn{7}{c}{ Hollandi } \\
\cline { 2 - 13 } & $\begin{array}{l}\text { N rate } \\
\text { (kg/ha) }\end{array}$ & $\mathbf{3 0}$ & $\mathbf{6 0}$ & $\mathbf{9 0}$ & $\mathbf{1 2 0}$ & Mean & $\mathbf{3 0}$ & $\mathbf{6 0}$ & $\mathbf{9 0}$ & $\mathbf{1 2 0}$ & Mean \\
\hline Traits & $\mathbf{L o g}$ & & & & & & & & & \\
\hline NBPE (TDW/Nt) & $\mathrm{X} 2$ & 0.18 & 0.18 & 0.17 & 0.18 & 0.18 & 0.13 & 0.12 & 0.11 & 0.11 & 0.12 \\
NUPE (Nt/NS) & $\mathrm{X} 3$ & 0.58 & 0.58 & 0.58 & 0.57 & 0.58 & 0.57 & 0.58 & 0.57 & 0.56 & 0.57 \\
NUEPY (GNY/NS) & $\mathrm{Y} 2$ & - & - & - & - & - & - & - & - & - & - \\
NBPE (TDW/Nt) & $\mathrm{X} 2$ & -0.09 & -0.10 & -0.07 & -0.07 & -0.08 & -0.02 & -0.05 & -0.03 & -0.05 & -0.04 \\
NUPE (Nt/NS) & $\mathrm{X} 3$ & 0.59 & 0.59 & 0.57 & 0.56 & 0.58 & 0.47 & 0.45 & 0.43 & 0.43 & 0.45 \\
GNY/TDW & $\mathrm{X} 4$ & 0.50 & 0.49 & 0.49 & 0.50 & 0.50 & 0.55 & 0.55 & 0.55 & 0.55 & 0.55 \\
\hline
\end{tabular}

Where, NUEGY = nitrogen use efficiency for grain yield; NUEPY = nitrogen use efficiency for protein yield; $\mathrm{HI}=$ harvest index; NBPE = nitrogen biomass production efficiency; NUPE = nitrogen uptake efficiency; GDW $=$ grain dry weight; $\mathrm{TDW}=$ total dry weight; $\mathrm{NS}=$ nitrogen supplied; $\mathrm{Nt}=$ total plant nitrogen and $\mathrm{GNY}=$ grain nitrogen yield.

Yet, NUPE accounted for higher variation in NUEGY of variety Hollandi at all $\mathrm{N}$ rates in which its contribution declined when the $\mathrm{N}$ rate increased from 60 to 120 $\mathrm{kg} \mathrm{N} \mathrm{ha}{ }^{-1}$. The relative contribution of NBPE was least as its value decreased with the increasing $\mathrm{N}$ rate from 30 to $90 \mathrm{~kg} \mathrm{ha}^{-1}$, but similar between 90 and $120 \mathrm{~kg}$ $\mathrm{N} \mathrm{ha}{ }^{-1}$. Compared to the mean relative contributions of NUPE and NBPE to NUEGY for variety Madda Walabu, the mean relative contributions of NUPE and NBPE to NUEGY for variety Hollandi was reduced, respectively, by 1 and $5 \%$. On the other hand, the relative contribution of HI to NUEGY for variety Hollandi was higher under all $\mathrm{N}$ rates compared with the contribution of the trait in variety Madda Walabu. The mean values across all $\mathrm{N}$ levels indicated 5\% higher relative contribution of HI to NUEGY in the local variety compared with the improved one. However, the relative contribution of NUTE in both varieties was similar. The result indicates that the total plant $\mathrm{N}$ utilization for grain yield in the local variety was highly influenced by the increased harvest index.

Less HI (which is mostly considered as a genetic trait), and higher NBPE and NUPE contributions to the variations in NUEGY for Madda Walabu compared to Hollandi indicates the higher effect of $\mathrm{N}$ supply on the use efficiency for grain yield. The relative contribution of NUPE to the variation in NUEPY of variety Hollandi was slightly decreased with each increase in $\mathrm{N}$ rate up to $90 \mathrm{~kg} \mathrm{~N} \mathrm{ha}^{-1}$ and remained unchanged when $\mathrm{N}$ rate increased from 90 to $120 \mathrm{~kg} \mathrm{ha}^{-1}$. The proportion of GNY to TDW in variety Hollandi had similar and higher contribution (55\%) to the variation in NUEPY under all $\mathrm{N}$ rates. The result was consistent with the reports of Moll et al.(1982),Van Sanford and MacKown (1986), Ortiz-Monasterio et al. (1997) and Muurinen (2007) who reported higher and variable contribution (decreased contribution with the increasing rate) of NUPE to NUEGY, but is in contrast with that of Isfan (1993) who found higher NUTE contribution. Van Sanford and MacKown (1986) reported 54 to $81 \%$ NUPE contribution to the variation in NUEGY and negative contribution of NBPE to variation in NUEPY. The authors also reported higher NUPE contributions to the variations in NUEPY compared with GNY/TDW which holds true for the improved variety in the present study. 
3.6 Associations between grain yield, protein content and NUE traits

Correlation coefficients indicated negative and significant association of grain yield with protein content $\left(r=-0.35^{* *}\right)$ indicating an inverse yield-protein relationship. NUPE had non-significant negative correlations with grain yield and protein content (Table 7). The small negative association of NUPE with these parameters illustrates the decrease of a trait with the increasing $\mathrm{N}$ rates that positively influenced the others. On the other hand, NBPE was positively associated with grain yield $\left(\mathrm{r}=0.34^{* *}\right)$. However, it had significant negative correlation $\left(\mathrm{r}=-0.56^{* * *}\right)$ with grain protein content. NUTE showed no correlations with grain yield. The trait had significant negative correlations with grain protein. On the other hand, NUPE showed significant positive correlation $(\mathrm{r}=$ $0.38^{* *}$ ) with NUTE but no correlation with NBPE. Significantly higher positive correlation $\left(r=0.49^{* * *}\right)$ was also observed between NUTE and NBPE. Corroborating these results, Ayoub et al. (1995) and Ortiz-Monasterio et al. (1997) reported negative associations of grain yield with protein content. Sinebo et al. (2004) found significant negative correlations of NUTE with grain protein content. Van Sanford and MacKown (1986) also reported significant positive correlations between the two major NUE component traits, NUPE and NUTE.

Table 7. Correlation coefficients between mean NUE and agronomic traits of bread wheat grown under different $\mathrm{N}$ rate and time of applications at Adaba, 2010 main cropping season

\begin{tabular}{lllllllll}
\hline & GY & GPC & NUPE & NBPE & NUTE & NUEGY & NUEPY & NHI \\
\hline GY & 1.00 & & & & & & & \\
GPC & $-0.35^{* *}$ & 1.00 & & & & & \\
NUPE & $-0.17 \mathrm{NS}$ & $-0.13 \mathrm{NS}$ & 1.00 & & & & \\
NBPE & $0.34^{* *}$ & $-0.56^{* * *}$ & $0.22 \mathrm{NS}$ & 1.00 & & & \\
NUTE & $0.02 \mathrm{NS}$ & $-0.42^{* * *}$ & $0.38^{* *}$ & $0.49 * * *$ & 1.00 & & & \\
NUEGY & $-0.08 \mathrm{NS}$ & $-0.35^{* *}$ & $0.83^{* * *}$ & $0.40^{* * *}$ & $0.78^{* * *}$ & 1.00 & & \\
NUEPY & $-0.25^{*}$ & $0.22 \mathrm{NS}$ & $0.79^{* * *}$ & $0.16 \mathrm{NS}$ & $0.51 * * *$ & $0.76^{* * *}$ & 1.00 & \\
NHI & $0.20 \mathrm{NS}$ & $0.42^{* * *}$ & $0.13 \mathrm{NS}$ & $0.16 \mathrm{NS}$ & $0.38^{* *}$ & $0.23 *$ & $0.58^{* * *}$ & 1.00 \\
\hline
\end{tabular}

Where, $\mathrm{GY}=$ grain yield; $\mathrm{GPC}=$ grain protein content $\mathrm{NUPE}=\mathrm{N}$ uptake efficiency; $\mathrm{NBPE}=\mathrm{N}$ biomass production efficiency; $\mathrm{NUTE}=\mathrm{N}$ utilization efficiency; $\mathrm{NUEGY}=\mathrm{N}$ use efficiency for grain yield; $\mathrm{NUEPY}=\mathrm{N}$ use efficiency for protein yield; $\mathrm{NHI}=\mathrm{N}$ harvest index. $\mathrm{NS}, * * *$ and $* * *=$ non-significant, significantly different at $5 \%, 1 \%$, and $0.1 \%$, respectively.

Both NUEGY and NUEPY were negatively correlated with grain yield, but the association was non significant for NUEGY and grain yield. Grain protein exhibited significantly higher negative associations with NUEGY with an $r$ value of $-0.35^{* *}$. Highly significant positive correlation coefficients were obtained for the association of NUEGY with NUPE, NBPE and NUTE $\left(\mathrm{r}=0.83^{* * *}, 0.40^{* * *}, 0.78^{* * *}\right.$, respectively). Non-significant, correlation coefficients were measured for the associations of NUEPY with grain protein and NBPE.

Association of NUEPY with NUPE, NUTE and NUEGY indicated significantly higher positive asso- 
ciations $\left(\mathrm{r}=0.79^{* * *}, 0.51^{* * *}\right.$ and $0.76^{* * *}$, respectively). NHI was positively correlated with all the traits. The correlation coefficients were significant for the association of NHI with, grain protein content, NUTE, NUEGY and NUEPY. In other studies, positive associations were also reported between NUPE, NBPE, NUTE and NHI traits (Van Sanford and MacKown, 1986; Sinebo et al., 2004; Muurinen,2007). The authors also reported positive correlations of the traits with the resultant $\mathrm{N}$ use efficiencies.

\section{Conclusions}

Low available soil $\mathrm{N}$ and reduced plant NUE are some of the major constraints limiting wheat yield and protein content in Ethiopia. Ensuring a well-balanced supply of $\mathrm{N}$ to the crop may result in higher grain yield and increased protein content. In this study, the improved variety produced higher grain yield at the highest $\mathrm{N}$ rate. $\mathrm{N}$ applications of $1 / 4 \mathrm{P}, 1 / 2 \mathrm{MT}$ and $1 / 4 \mathrm{~A}$ resulted in the highest yield of the variety. NUPE, NBPE and NUTE were significantly decreased with increased $\mathrm{N}$ application rates. The improved variety had the highest NUTE in response to $\mathrm{N}$ applications of $1 / 4 \mathrm{P}, 1 / 2 \mathrm{MT}$ and $1 / 4 \mathrm{~A}$. N applications of $1 / 4 \mathrm{P}, 1 / 2 \mathrm{MT}$ and $1 / 4 \mathrm{~A}$ resulted in higher NUEGY of Madda Walabu. NUPE explained higher variation in NUEGY of the varieties with higher contributions at the lowest $\mathrm{N}$ rate. Higher contribution of HI was measured for the local variety while higher NUPE and NBPE contributions were measured for the improved variety. NUPE also explained higher variation in NUEPY of improved variety, but for local variety the trait was more explained by GNY/TDW. The resultant NUEGY showed positive and significant association with the component traits. NUEPY highly correlated with NUPE and NUTE, but not associated with NBPE. Generally the result indicated that $\mathrm{N}$ fertilizer rate and time of application markedly affected yield performance and $\mathrm{N}$ use efficiency of the improved variety.

\section{Acknowledgements}

This research was funded by grants from Local Seed Business (LSB) Project, which is sponsored by the Netherland Government through Wageningen University and the Royal Netherlands Embassy in Ethiopia. Sinana Agricultural Research Center and Haramaya University are highly acknowledged for the facilitation of field and laboratory research works. The excellent assistance of Habtamu Tadese and Debele Tsegaye in data collection, field and laboratory works are highly valued.

\section{References}

American Association Cereal Chemists (AACC). 2000. Approved Methods of the American Association Cereal Chemists. American Association of Cereal Chemists, Inc., St. Paul, Minnesota.

Ashraf, M., Azam, F. 1998. Fate and interaction with soil $\mathrm{N}$ of fertilizer ${ }^{15} \mathrm{~N}$ applied to wheat at different growth stages. Cereal Res. Commun. 26, 397-404.

Ayoub, M., Guertin, S., Smith, D. L. 1995. Nitrogen fertilizer rate and timing effect on bread wheat protein in eastern Canada. Crop Sci. 174, 337-349.

Banziger, M., Feil, B., Schmid, J.,E., Stamp, P. 1994 b. Utilization of late-applied nitrogen by spring wheat genotypes. Eur. J. Agron. 3: 63-69.

Bekele Hundie, H., Verkuijl Mwangi, W., Tanner, D. 2000. Adoption of Improved Wheat Technologies in Adaba and Dodola Woredas of the Bale Highlands, Ethiopia. In: D. Tanner, (ed.). Proceedings of the Second National Wheat Workshop. International Maize and Wheat Improvement Center (CIMMYT) and Ethiopian Agricultural Research Organization (EARO). Addis Ababa, Ethiopia, pp. 1-26. 
Blankenau, K., Olfs, H. W., Kuhlmann, H. 2002. Strategies to improve the use efficiency of mineral fertilizer nitrogen applied to winter wheat. $J$. Agron. Crop Sci. 188, 146-154.

Brian, N. O., Mohamed, M., Joel, K. R. 2007. Seeding rate and nitrogen management effects on spring wheat yield and yield components. Am. J. Agron. 99,1615-1621.

Central Statistical Agency (CSA). 2010. Agricultural sample survey 2009/10. Report on area production of crops (private peasant holdings, Meher Season). The FDRE statistical bulletin Vol. 391, Addis Ababa, Ethiopia, 79 p.

Chapman, H. D. 1965. Cation exchange capacity by ammonium saturation. In: C. A., Black, L. E. Ensminger, F. E. Clark (Eds.). Method of soil analysis. American Society of Agronomy. Madison Wisconsin, USA, pp. 891-901.

Cooper, M., Woodruff, D. R., Phillips, I. G., Basford, K. E., Gilmour, A. R. 2001. Genotype-bymanagement interactions for grain yield and grain protein concentration of wheat. Field Crops Res. 69, 47-67.

Dhugga, K. S., Waines, J. G. 1989. Analysis of nitrogen accumulation and use in bread and durum wheat. Crop Sci. 29, 1232-1239.

Feil, B. 1992. Breeding progress in small grain cereals- a comparison of old and modern cultivars. Plant Breeding 108, 1-11.

Feil, B. 1997. The inverse yield-protein relationship in cereals: possibilities and limitation for genetically improving the grain protein yield. Trends in Agronomy 1, 103-119.

Food and Agriculture Organization of the United Nations (FAO), 2008. FAO fertilizer and plant nutrition bulletin: Guide to laboratory establishment for plant nutrient analysis. FAO, Rome, Italy, 203 p.
Gouis, J. L., Beghin, D., Heumez, E., Pluchard, P. 2000. Genetic differences for nitrogen uptake and nitrogen utilization efficiencies in winter wheat. Eur. J. of Agron. 12, 163-173.

Hussain, M. I., Shah, S. H. 2002. Growth, yield and quality response of three wheat (Triticum aestivum L.) varieties to different levels of $\mathrm{N}, \mathrm{P}$ and $\mathrm{K}$. Int. J.of Agri. and Bio., 4(3), 362-364.

Iqtidar, H., Muhammad, A. K., Ejaz, A. K. 2006. Bread wheat varieties as influenced by different nitrogen levels. J Zhejiang Univ Sci. 7(1), 70-78.

Jackson, M. L. 1962. Soil chemical analysis. New Delhi, Prentice Hall of India Pvt. Ltd, 498 p.

Jan, M. T., Khan, J. M., Khan, A., Arif, M., Shafi, M., Nullah, N. 2010. Wheat nitrogen indices response to nitrogen source and application time. Pak. $J$. Bot. 42(6), 4267-4279.

Kumari, K., Sharma, M., Sharma, R . K., Balloli, S. S. 2000. Effect of late application of nitrogen on yield and protein content of wheat. Annals of $\mathrm{Ag}$ ric. Res. 21 (1), 288-291.

Legg, J. O., J. J. Meisinger, 1982. Soil nitrogen budgets Nitrogen balance, and cycle. Agron-A-SerMonogr-Am-Soc-Agron, Madison, 566 p.

May, L., Van Sanford, D. A., MacKown, C. T., Cornelius, P. L. 1991. Genetic variation for nitrogen use in soft red hard red winter wheat populations. Crop Sci. 31, 626-630.

Moll, R. H., Kamprath, E. J., Jackson, W. A. 1982. Analysis and interpretation of factors which contribute to efficiency of nitrogen utilization. Agron. J. $74,562-564$.

Moll, R. H., Kamprath, E. J., Jackson, W. A. 1987. Development of nitrogen-efficient prolific hybrids of maize. Crop Sci. 27, 181-186. 
Muurinen, S. 2007. Nitrogen dynamics and nitrogen use efficiency of spring cereals under Finnish growing conditions. Yliopistopaino, 29, 1-38.

Olsen S. R., Cole, C. W., Watanabe, F. S., Dean, L. A. 1954. Estimation of available phosphorous in soils by extraction with sodium bicarbonate. Soil Sci. 96, 308-12.

Ortiz-Monasterio, J. I., Sayre, K. D., Rajaram, S., McMahon, M. 1997. Genetic progress in

wheat yield and nitrogen use efficiency under four nitrogen rates. Crop Science 37, 898-904.

Roberts, T. L. 2008. Improving Nutrient Use Efficiency. Turk J. Agric. 32, 177-182.

Rodgers, C.O., Barneix, A. J. 1988. Cultivar differences in the rate of nitrate uptake by intact wheat plants as related to growth rate. Physiologia Plantarum. 72, 121-126.

Roy R.N., Finck, A., Blair, G. J., Tandon, H. L. 2006. Plant nutrition for food security: A guide for integrated nutrient management. FAO Fertilizer and Plant Nutrition Bulletin 16. Food and Agriculture Organization of the United Nations, Rome, Italy, 368 p.

Sinebo,W., Gretzmacher, R., Edelbauer, A. 2004. Genotypic variation for nitrogen use efficiency in Ethiopian barley. Field Crops Res. 85, 43-60.

Singh, V. P., Arora, A. 2001. Intraspecific variation in nitrogen uptake and nitrogen utilization efficiency in wheat (Triticum aestivum L.). Crop Sci. 186, 239-244.

Tanner, D., Amanuel, G., Asefa, T. 1993. Fertilizer effect on sustainability in the Wheat based smallholder-farming systems of southeastern Ethiopia. Field Crops Res. 33, 235-248.

Teklu, E., Hailemariam, T. 2009. Agronomic and economic efficiency of manure and urea fertilizers use on vertisols in ethiopian highlands. J.Agri. Sci. 8(3), 352-360.
Tilahun G., Feyissa, T., Kedir N., Genene G., Habtamu S., Ashinie B., Abdo W. 2008. Recommendations of production management practices. pp. 39-46. In: N. Kedir, G. Tilahun and A. Allo (eds.). Fifteen years achievements. Oromia Agricultural Research Institute, Sinana Agricultural Research Center, Bale Robe, Ethiopia, 259, p.

Tilman, D., Cassman, K. G., Matson, P. A., Naylor, R., and Polasky, S. 2002. Agricultural sustainability and intensive production practices. Nature. 418, 671-677.

Tran, T. S., Tremblay, G. 2000. Recovery of N-15-labeled fertilizer by spring bread wheat at different $\mathrm{N}$ rates and application times. Can. J. Soil Sci. 80, 533-539.

Van Sanford, D.A., MacKown, C. T. 1986. Variation in nitrogen use efficiency among soft red winter wheat genotypes. Theor. Appl. Genet. 72, 158-163.

Walkley, A.J., Black, I. A. 1934. Estimation of soil organic carbon by the chromic acid titration method. Soil Sci., 37, 29-38.

Wissum, M., Mazzola, M., Picard, C. 2009. Novel approaches in plant breeding for Rhizosphere related traits. Plant Soil. 321, 409-430.

Wuest, S. B., Cassman, K. G. 1992b. Fertilizer-nitrogen use efficiency of irrigated wheat: II. Partitioning efficiency of pre-plant versus late-season application. Agron. J. 84: 689-694.

Zadoks, J. C., Chang, T. T., Konzak, C. F. 1974. A decimal code for the growth stages of cereals. Weed Res. 14, 415-421.

Zafar, J., Muhammad, F. C. 2007. Effects of soil and foliar application of different concentrations of NPK and foliar application of (NH4) $)_{2} \mathrm{SO}_{4}$ on growth and yield attributes in wheat (triticum aestivum. 1). Pak. J. Pl. Sci. 13 (2), 119-128. 
